\title{
Rafał Makała
}

Technische Universität, Berlin

ORCID: 0000-0001-8083-4766

\section{Dwa kościoły. Budownictwo kultowe w międzywojennych Niemczech jako przestrzeń modernistycznych eksperymentów ${ }^{1}$}

DOI: https://doi.org/10.26881/porta.2020.19.17

Trzecia dekada i początek czwartej dekady XX w., tak ważne dla architektury niemieckiej awangardy, były też okresem intensywnego rozwoju budownictwa kultowego dla dominujących ówcześnie w Niemczech wyznań - luterańsko-reformowanego i rzymskokatolickiego. Kataklizm pierwszej wojny światowej i kryzys ideologicznych podstaw państwa stworzonego dzięki bismarckowskiemu zjednoczeniu w $1871 \mathrm{r}$. spowodowały - nieco paradoksalnie - zwrot laicyzującego się wcześniej społeczeństwa w stronę religii, co z kolei przyczyniło się do rozwoju ruchów dążących do reformy Kościołów, zarówno katolickiego, jak i ewangelickich. W efekcie nastąpił rozkwit budownictwa kultowego, widoczny zwłaszcza $\mathrm{w}$ drugiej połowie lat dwudziestych ( $\mathrm{tj}$. po względnym ustabilizowaniu się sytuacji ekonomicznej), stanowiąc obszar intensywnych eksperymentów z nowymi formami i nowymi sposobami budowania semantyki kościoła². W sytuacji politycznej i społecznej Niemiec, na fali ruchów

1 Publikowany tekst powstał w oparciu o prowadzone przez autora badania dotyczące architektury sakralnej pierwszej połowy XX w. oraz badania twórczości Adolfa Thesmachera, Oba projekty mają na celu wydanie obszerniejszych publikacji podsumowujących wyniki analiz.

2 Początki ruchów dążących do odnowy Kościoła katolickiego w Niemczech sięgają połowy XIX w. i wiążą się z działalnością m.in. Wilhelma Ernsta von Kettelera czy błogosławionego Adolfa Kolpinga. W okresie międzywojennym najważniejsze znaczenie miały prace teologa Johannesa van Ackena, zwłaszcza manifest Christozentrische Kunst (1922), postulujący stosowanie nowych technologii w budownictwie sakralnym tak, by zmniejszyć dystans dzielący Kościół od otaczającego go świata, zob. Heinrich Spaemann, Acken, Johannes van [w:] Lexikon für Theologie und Kirche, Hg. Josef Höfer, Karl Rahner, Bd. 1, Freiburg im Breisgau 1957², s. 112. W środowisku protestanckim zasadnicze znaczenie miały debaty toczone w związku z II (1906) i III (1928) Kongresem Budownictwa Kościelnego Protestantyzmu (Kongress für Kirchenbau des Protestantismus), zob. Gerhard Langmaack, Evangelischer Kirchenbau im 19. und 20. Jahrhundert. Geschichte - Dokumentation - Synopse. Kassel 1971, s. 17-34; Hans Christoph Brennecke, Protestantischer Kirchenbau an der Wende zum 20. Jahrhundert [w:] Geschichte des protestantischen Kirchenbaues. Festschrift für Peter Poscharsky zum 60. Geburtstag, Hg. Klaus Raschzok, Reiner Sörries, Erlangen 1994, s. 119-127; Manuela Klauser, Ikonische Kirchen. Pfarrkirchenbau an Rhein und Ruhr zwischen Historismus und Moderne, Regensburg 2019, s. 184-233, 322-462 (tamże literatura przedmiotu). 
Rafał odnowy - katolickich i protestanckich - pojawiły się pytania m.in. o charakter Makała kościoła jako budowli, jego funkcjonalność, możliwości wyrażania architekturą charakteru religii i wizualizowania nowych koncepcji Kościoła jako wspólnoty w nowoczesnym społeczeństwie ${ }^{3}$. W odpowiedzi powstawały nowatorskie koncepcje kościołów - od abstrakcyjnych, minimalistycznych dzieł Rudolfa Schwartza, przez funkcjonalistyczne pomysły Otto Bartninga, aż po ekspresyjne projekty Dominikusa Böhma, służące tworzeniu mistycznej atmosfery za pomocą nowoczesnych form ${ }^{4}$. To właśnie w architekturze kościołów dają się znakomicie zaobserwować zmagania nurtów awangardy międzywojennej. Szczególnie widoczne jest napięcie między dążeniem do radykalnej modernizacji a chęcią odwoływania się do tradycji ${ }^{5}$. Protagoniści niemieckiej awangardy architektonicznej, Walter Gropius czy Ludwig Mies van der Rohe, nie interesowali się budownictwem kultowym, pozostawiając to zadanie w rękach twórców duchowo związanych z oboma wyznaniami, często głęboko zaangażowanych religijnie. A ci nie wahali się wykorzystywać zdobyczy awangardy, ale traktowali je jak zbiór kompozycyjnych czy formalnych innowacji, z którego można dowolnie czerpać. W tym kontekście interesująca jest kwestia wymiany doświadczeń i wzajemnych inspiracji dwóch najważniejszych w ówczesnych Niemczech wyznań - ewangelicko-reformowanego i rzymskokatolickiego ${ }^{6}$. Przykładem

3 Zarówno ewangelicki, jak i katolicki ruch odnowy kładł nacisk na wspólnotowy wymiar życia religijnego, co było konsekwencją doświadczeń pierwszej wojny światowej, zob. Wolfgang Pehnt, Deutsche Architektur seit 1900, Ludwigsburg-München 2006², s. 107.

4 Najbardziej znanym przykładem rozwiązań funkcjonalistycznych były pomysły Otto Bartninga, przede wszystkim pomysł „Sternkirche” („kościoła gwieździstego”) z 1922 r. oraz wybudowanego na kolońskiej wystawie Pressa w 1927 r. i wielokrotnie powtarzanego w późniejszych latach „Notkirche” (kościoła z elementów prefabrykowanych do szybkiego wybudowania na nowo powstających osiedlach). Najnowsze omówienie twórczości wypowiedzi teoretyczno-artystycznych Bartninga w katalogu poświęconej mu wystawy, zob. Werner Durth, Wolfgang Pehnt, Sandra Wagner-Conzelmann, Otto Barning, Architekt einer sozialen Moderne, Darmstadt 2017. Na temat twórczości Dominikusa Böhma zob. Raum ist Sehnsucht. Der Kirchenbaumeister Dominikus Böhm 1888-1955 [katalog wystawy], Hg. Wolfgang Voigt, Ingeborg Flagge, Deutsches Architekturmuseum, Frankfurt am Main, Tübingen-Berlin 2005. Na temat twórczości Rudolfa Schwarza zob. Wolfgang Pehnt, Die Plangestalt des Ganzen. Der Architekt und Stadtplaner Rudolf Schwarz (1897-1961) und seine Zeitgenossen, Köln 2011 (tamże literatutra przedmiotu). W polskiej literaturze badawczej zob. m.in. Ewa M. Żurawska, Twórczość Dominikusa Böhma na Śląsku, „Przestrzeń i Forma” 2012, nr 16, s. 623-654; nr 17, s. 517-530; nr 18, s. 291-304; Jerzy Gorzelik, Kościót św. Józefa w Zabrzu - arcydzieło architektury sakralnej, „Zeszyty Edukacji Kulturalnej” 2005, t. 48, s. 154-163; Ewa Chojecka, Kościót św. Józefa w Zabrzu na tle krajobrazu artystycznego Górnego Ślaska, Katowice 1999. O twórczości Böhma wspomina też m.in. Cezary Wąs, Antynomie współczesnej architektury sakralnej, Wrocław 2008, s. 12, 57, 66-69.

5 Christian Welzbacher, Kirchenbau und Moderne (1920-1940). Anmerkungen zu einer traditionsgebundenen Baugattung, „Kritische Berichte” 2007, Bd. 35, H. 1, s. 33-46.

6 Podobieństwo katolickiego i protestanckiego budownictwa kultowego - zdumiewające, zważywszy na różnice dogmatyczne i generalną wrogość obu wyznań - jest wyraźnie widoczne przynajmniej od połowy XIX w. i wynika ze sposobu kształcenia architektów na państwowych uczelniach, a także z szybkiego upowszechniania się wzorów dzięki prasie fachowej. W Niemczech ważny był aspekt narodowy, skłaniający architektów i zleceniodawców do sięgania po te same 
pars pro toto tego zjawiska jest zestawienie dwóch powstałych niemal w tym samym czasie, mało znanych, choć znakomitych budowli: katolickiego kościoła św. Antoniego Padewskiego w Pile, zbudowanego w latach 1928-1930 według projektu Hansa Herkommera, i ewangelickiego Kościoła Krzyża w Szczecinie, wzniesionego w latach 1929-1931 przez Adolfa Thesmachera ${ }^{7}$. Obie budowle miały być nie tylko kościołami parafialnymi, lecz także pełnić funkcje reprezentacyjne. Niezwykle ważnym czynnikiem wpływającym na ich formę była też chęć zaprezentowania się miejscowych elit jako środowisk nowoczesnych.

Wybudowanie kościoła św. Antoniego w Pile wiązało się z ustanowieniem w 1923 r. Niezależnej Prałatury Pilskiej (Freie Prälatur Schneidemühl), administrującej tereny diecezji poznańskiej i chełmińskiej, które po traktacie wersalskim z 1919 r. pozostały w granicach państwa niemieckiego ${ }^{8}$. Status Prałatury zobowiązywał do posiadania okazałej siedziby - kościoła oraz budynków biurowych i mieszkalnych. W Pile istniały w tym czasie dwie świątynie katolickie należące do tej samej parafii: barokowa fara św. św. Janów i kościół Świętej Rodziny, wybudowany w latach 1912-1915 według projektu Oscara Siedego z Berlina. Wydawać by się mogło, że ta druga budowla - neobarokowa trójnawowa bazylika $z$ transeptem i monumentalną dwuwieżową fasadą - mogłaby doskonale pełnić funkcje reprezentacyjne. Jednak prałat Maximilian Kaller, zaraz po przyjeździe do Piły, podjął decyzję o budowie nowego obiektu kultowego z zapleczem biurowo-mieszkalnym. Wybór lokalizacji - budowla miała stanąć na Przedmieściu Bydgoskim, na rogu Ackerstrasse i Königsstrasse (obecnie ulice Ludowa i F.D. Roosevelta), wynikał nie tyle z potrzeb duszpasterskich, ile $\mathrm{z}$ możliwości finansowych diecezji, a przede wszystkim z faktu posiadania

wzorce. Obszernie pisała o tym zjawisku na przykładzie Wrocławia XIX w. Agnieszka Zabłocka-Kos, Sztuka. wiara. uczucie. Alexis Langer - ślaski architekt neogotyku, Wrocław 1996, s. 114-131; zob. też Klauser, Ikonische Kirchen..., s. 55-101.

7 O kościele św. Antoniego w Pile obszerną i bogatą faktograficznie (choć pozbawioną przypisów) monografię napisał Patryk Jankiewicz, Kościól św. Antoniego w Pile. Przewodnik. Piła 2009. Dawny Kościół Krzyża w Szczecinie pojawia się incydentalnie w różnych publikacjach, zob. m.in. Robert Dawidowski, Ryszard Długopolski, Adam M. Szymski, Architektura modernistyczna lat 1928-1940 na obszarze Pomorza Zachodniego, Szczecin 2001, s. 87, 230-231; Maria Glińska, Niderlandyzm w sztuce Pomorza Zachodniego w czasach nowożytnych [w:] Niderlandyzm w sztuce polskiej. Materiały Sesji Stowarzyszenia Historyków Sztuki, Toruń, grudzień 1992, red. Tadeusz Chrzanowski, Warszawa 1995, s. 186-188. Najobszerniej omawia go Alina Stefańska, Architektura kompromisu. Europejskie źródła i szczecińskie realizacje. Analiza języka formalnego Adolfa Thesmachera na przykładzie kościołów: pw. Królowej Korony Polskiej $i$ św. Andrzeja Boboli (Kreuzes- $i$ Nicolaikirche) w Szczecinie, „Materiały Zachodniopomorskie” 1996, t. 42, s. 449-452, 454-460; zob. też Helmut Heyen, Die Kirchen Stettins und ihre Geschichte, Stettin 1936, s. 298.

8 W 1923 r. Pius XI ustanowił dla tych parafii Administrację Apostolską w Tucznie, przeniesioną w 1927 r. do Piły. W 1930 r., po podpisaniu konkordatu z Niemcami, przekształcono ją w Niezależną Prałaturę Pilską. Prałatura obejmowała 67 parafii i 6 wikariatów lokalnych z niemal 137000 wiernych (w 1940 r.). Informacje na temat historii prałatury zob. Jankiewicz, Kościót św. Antoniego..., s. 24-28. 
Rafał przez parafię odpowiedniej działki, pozyskanej pod budowę kościoła jeszcze Makała przed pierwszą wojną światową. W $1927 \mathrm{r}$. postanowiono rozpisać ograniczony konkurs na projekt, do którego zaproszono - oprócz miejscowego budowniczego Karla Sommera - architektów o ogólnoniemieckiej renomie specjalizujących się w budowaniu kościołów katolickich, m.in. Dominikusa Böhma i Hansa Herkommera. Temu ostatniemu powierzono w połowie $1928 \mathrm{r}$. sporządzenie projektu wykonawczego, sugerując przy tym uwzględnienie etapowej realizacji przedsięwzięcia. W ramach pierwszego etapu wybudowano najpierw kościół, konsekrowany już na wiosnę 1930 r., i dostawiony do północnego ramienia transeptu pomocniczy budynek mieszkalno-handlowy. Projektowany przez Herkommera wirydarz z budynkami prałatury, przylegający do kościoła od południa, miał zostać wzniesiony w drugim etapie, jednak dalszą realizację uniemożliwił wybuch drugiej wojny światowej. Obecne budynki klasztoru kapucynów (którzy przejęli kościół w 1945 r.) powstały dopiero w latach osiemdziesiątych XX w. i jedynie nawiązują do pierwotnego projektu?.

Kościół św. Antoniego należy do grupy niezwykle interesujących dzieł Herkommera, powstałych na przełomie lat dwudziestych i trzydziestych XX w. i obejmujących m.in. kościół Serca Jezusowego w Ratingen koło Düsseldorfu (1928-1929), kościół św. Anny w St. Wedel w kraju Saary (1929-1930) i kościół św. Józefa w Schömbergu w Schwarzwaldzie koło Stuttgartu (1928-1929)10. Mimo wyraźnych różnic stanowiły one rozwinięcie koncepcji najsłynniejszej budowli kultowej Herkommera - kościoła Matki Boskiej Bolesnej w Bockenheim we Frankfurcie nad Menem, wybudowanego w latach 1927-1929 dla Katolickiego Niemieckiego Związku Kobiet (Katholischer Deutscher Frauenbund), stąd jego zwyczajowa nazwa: Kościół Pokoju Kobiet (Frauenfriedenskirche) ${ }^{11}$ (il. 1). Budowla ta miała charakter pomnikowy (jako upamiętnienie poległych w pierwszej wojnie światowej) i wotywny (symbolizując działania niemieckich katoliczek na rzecz pokoju). Podobnie jak kościół św. Antoniego w Pile frankfurcka świątynia miała zatem nie tylko służyć zwykłej pracy duszpasterskiej, lecz także pełnić funkcje reprezentacyjne, choć oczywiście możliwości finansowe

9 Ibidem, s. 28-30, 69-80, 179-180.

10 Marlen Dittmann, Die Baukultur im Saarland 1904-1945, „Saarland Hefte” 2004, Bd. 3. s. $45-47$.

11 Twórczość Herkommera została opracowana monograficznie przez Marinę Lahmann w dysertacji doktorskiej Das Werk des Architekten Hans Herkommer (1887-1956) und sein Bezug $z u$ den Strömungen der deutschen Architektur in der ersten Hälfte des 20. Jahrhunderts (1990, Uniwersytet w Moguncji). Rozprawa ta nigdy nie ukazała się jednak drukiem, toteż najważniejszą monograficzną pozycję poświęconą temu architektowi stanowi Moderne Architektur exemplarisch. Hans Herkommer (1887-1956), Hg. Mathias Schirren, Kaiserslautern 2010. Na temat frankfurckiej świątyni zob. Geschichte der Kirchen in Sankt Marien, Hg. Kirchengemeinde Sankt Marien Frankfurt am Main, Frankfurt am Main 2017; Heike Risse, Frühe Moderne in Frankfurt am Main. 1920-1933, Frankfurt am Main 1984, s. 171; W. H. [Werner Hegemann], Die Frauenfriedenskirche in Frankfurt am Main. Architekt: Hans Herkommer, „Wasmuths Monatshefte für Baukunst und Städtebau" 1930, Bd. 14, s. 406-410. 


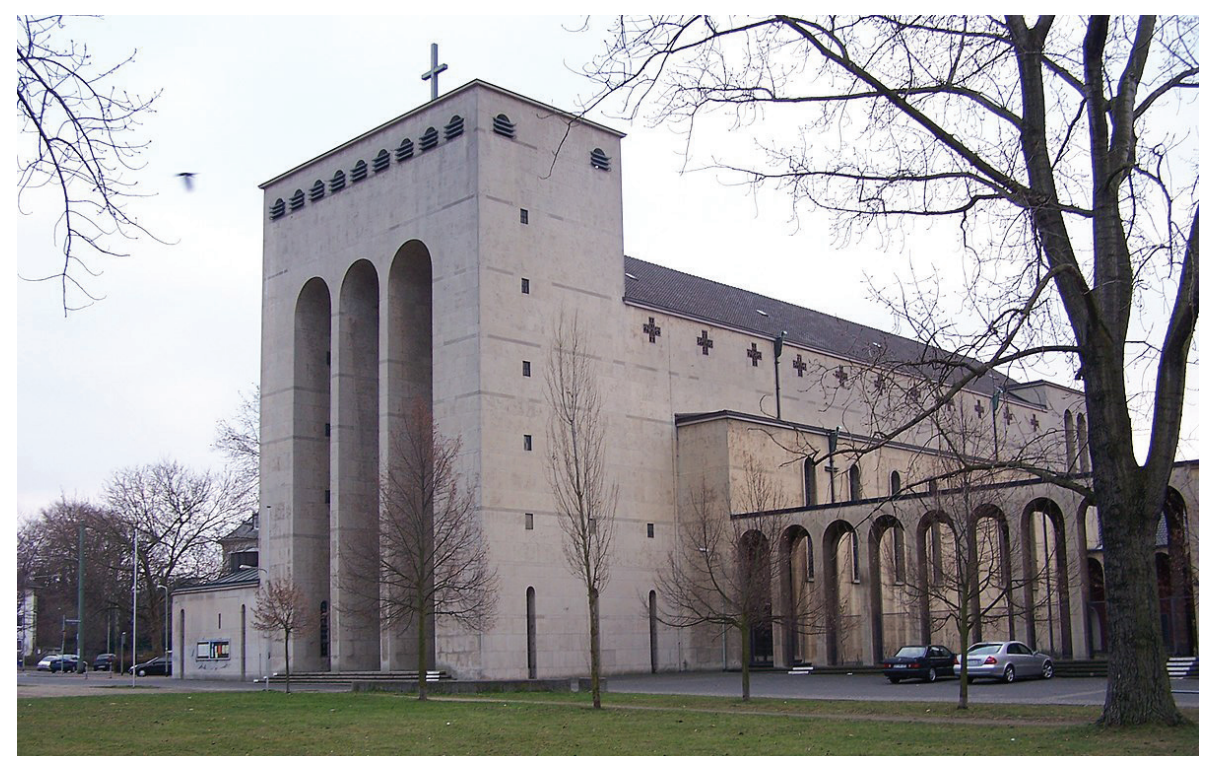

Dwa kościoły...

Il. 1. Hans Herkommer, Kościół Pokoju Kobiet (Frauenfriedenskirche), Frankfurt nad Menem, 1927-1929, repr. za: Melkom, Wikimedia Commons, licencja CC BY-SA 3.0.

zleceniodawców, ogólnoniemieckiej organizacji kościelnej i „kresowej” prałatury, były nieporównywalne.

Kościół św. Antoniego prezentuje się, podobnie jak frankfurcka świątynia, jako trójnawowa bazylika z potężną wieżą tworzącą rodzaj masywu zachodniego i latarnią nad chórem (il. 2). Po południowej stronie kościoła Herkommer zaplanował prostokątny wirydarz, od wschodu i południa zamknięty budynkami prałatury i plebanii, a od zachodu (od ulicy) - murem z trójosiowym portalem pośrodku. Analogiczne rozwiązanie architekt zastosował we Frankfurcie, projektując po północno-zachodniej stronie kościoła wirydarz z monumentalnym arkadowym portykiem od strony fasady. Obie budowle wzniesiono w oparciu stalowy szkielet wypełniony pustakami. We Frankfurcie ściany obłożono płytami sztucznego kamienia na bazie wapienia muszlowego, w Pile pokryto chropawym, jasnoszarym, niemal białym tynkiem, z którym kontrastowały obite blachą cynkową drzwi i wykonane z tego samego materiału obróbki blacharskie ${ }^{12}$. W obu projektach widoczne jest też dążenie do addycyjnego skomponowania budowli z prostych kubicznych brył, z pozbawionymi dekoracji elewacjami, których artykulacji służą jedynie okna (szczególnie interesujące dla tematyki niniejszego artykułu są wąskie, półkoliście zamknięte okna naw bocznych). $\mathrm{W}$ istocie jest to zatem kompozycja posługująca się estetyką wypracowaną w kręgu międzynarodowej awangardy. Herkommer sprecyzował swoje poglądy na ten temat w publikacji Kirchliche Kunst

12 Po drugiej wojnie światowej kościół był kilkakrotnie malowany, a na początku XXI w. północą elewację ocieplono styropianem. 


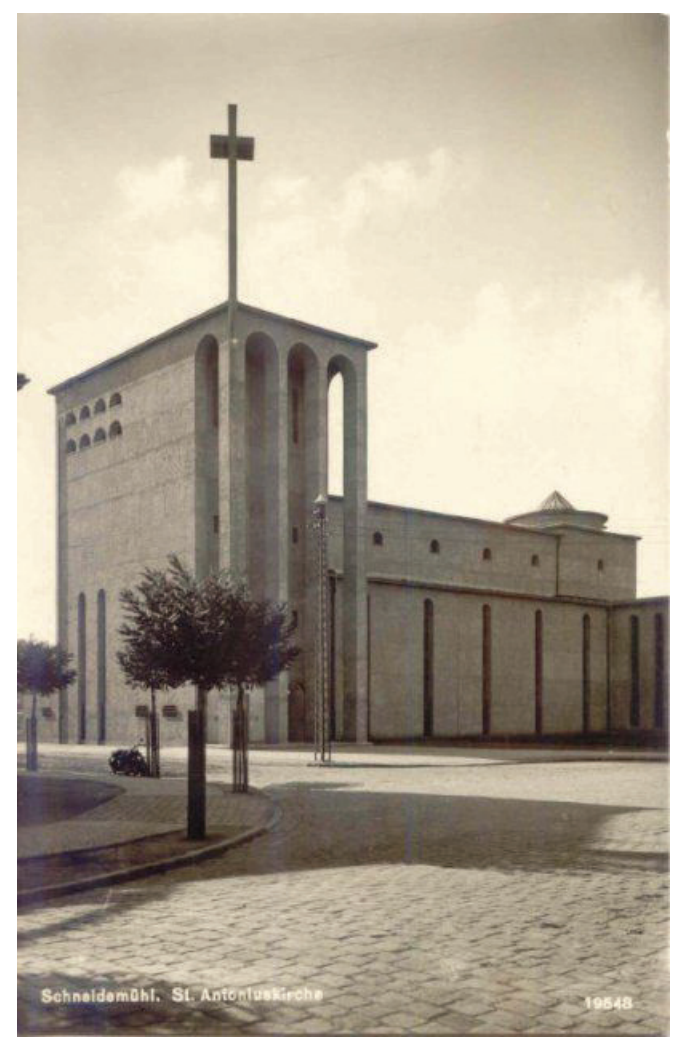

Il. 2. Hans Herkommer, kościół św. Antoniego w Pile, 1928-1930, widok od strony skrzyżowania ulic, stan z okresu międzywojennego, repr. za: Tomasz Sachanowicz, Architektura w Szczecinie..., https://www.blogger.com/profile/ 04175562884831164762 der Gegenwart, wydanej w 1930 r. z okazji wystawy pod tym samym tytułem, która odbyła się w Stuttgarcie. Pisał o konieczności projektowania budowli pomyślanej jako kompleks jasno definiowanych brył geometrycznych, jednak - w przeciwieństwie np. do architektów z kręgu Bauhausu - twierdzil, że to tylko środek do osiągnięcia celu, jakim jest wywołanie emocji religijnych u odwiedzających świątynię ${ }^{13}$.

Różnice między frankfurcką i pilską świątynią są równie zauważalne jak podobieństwa, przy czym kościół św. Antoniego prezentuje się jako budowla znacznie bardziej nowatorska. W obu obiektach Herkommer zaprojektował potężną wieżę, inaczej jednak rozwiązał ich frontowe elewacje. W budowli frankfurckiej wejście umieszczone jest na osi kościoła i zaakcentowane trzema kolosalnymi niszami, które oglądane z ukosa, z niewielkiego placu przed kościołem, przypominają portyk. Ich górne partie wypełniono dekoracją mozaikową, w środkowej zaś umieszczono wielką, barwnie glazurowaną figurę Madonny ${ }^{14}$. W Pile kolosalny arkadowy portyk kryjący główne wejście zaprojektowano po północnej stronie wieży, dzięki temu główne wejście zwrócone jest w kierunku niewielkiego placu przy skrzyżowa-

niu Ackerstrasse i Königsstrasse, powstałego między gmachem kościoła a przylegającą doń prostopadle kaplicą św. Antoniego i stanowiącym jej przedłużenie budynkiem. Nad północno-wschodnim narożnikiem wieży Herkommer zaprojektował wysoki, betonowy krzyż, będący przedłużeniem smukłej szkarpy dostawionej ukośnie do narożnika wieży. Motyw ten miał istotne znaczenie w formułowanej przez Herkommera koncepcji architektury sakralnej. We wspomnianej już książce z 1930 r. podkreślał, że skoro wieże kościelne nie stanowią już dominant

13 Hans Herkommer, Kirchliche Kunst der Gegenwart, Stuttgart 1930, s. 8.

14 Figura ta kojarzy się oczywiście z mozaikową rzeźbą Madonny na zewnętrznej elewacji chóru kościoła zamkowego w Malborku, trudno jednak orzec, czy Herkommer inspirował się tym historycznym wzorem. Z pewnością architektura Malborka była w jego czasach znana dzięki publikacjom i wykorzystywana jako wzór w procesie kształcenia architektów, zob. Wezlbacher, Kirchenbau und Moderne..., s. 38. 
w pejzażu miejskim, wielki podświetlony krzyż staje się optycznym sygnałem obecności chrześcijaństwa we współczesnym świecie, tak jak dźwięk dzwonów jest sygnałem akustycznym ${ }^{15}$. Tego rodzaju krzyże pojawiały się wówczas często zarówno w jego twórczości (np. w kościele św. Anny w St. Wendel), jak i w pracach innych architektów, m.in. wspominanego już Böhma (np. w kościele Chrystusa Króla w Bischofsheim z lat 1925-1926 ${ }^{16}$ ). Nowością pilskiej realizacji jest wyprowadzenie krzyża ze szkarpy i ukośne ustawienie go wobec osi kościoła, wynikające z lokalizacji budowli, dzięki czemu krzyż był doskonale widoczny $\mathrm{z}$ obu przecinających się ulic. Ten interesujący motyw nie jest jedynym, który przypomina rozwiązania stosowane przez rywali Herkommera, np. słynny kościół kamilianów w Mönchengladbach (1929-1931) Böhma czy kościół św. Krzyża we Frankfurcie-Bornheim (1928-1929) Martina Webera - oba zaprojektowane w tym samym roku co pilska świątynia ${ }^{17}$. Zwłaszcza drugi z wymienionych obiektów, z kolosalnym arkadowym portykiem w bocznych elewacjach wieży, wykazuje uderzające podobieństwo do kościoła św. Antoniego. Kompozycja budowli Webera jest jednak znacznie bardziej symetryczna, co sprawia, że dzieło Herkommera wydaje się w porównaniu z nią bardziej nowatorskie w sposobie kształtowania bryły, zdecydowanie bardziej innowacyjnej niż w jego wcześniejszych realizacjach, łącznie z Kościołem Pokoju Kobiet. Manifestacyjnie ascetyczna, kubiczna bryła budowli, eksponująca wielkie, puste płaszczyzny ścian, musiała prezentować się niezwykle nowocześnie na tle dotychczasowej architektury prowincjonalnego, wschodnioniemieckiego miasta. Również na tle najbliższego otoczenia - osiedla dwupiętrowych domów mieszkalnych w duchu tzw. szkoły stuttgarckiej - kościół św. Antoniego jawił się jako obiekt wręcz radykalnie nowatorski. Taka sytuacja kojarzy się z niezrealizowanymi projektami kościoła kamilianów na Placu Targów Poniedziałkowych (Montagsmarkt, obecnie pl. Traugutta) w Zabrzu (ówcześnie Hindenburg), kreślonymi w latach 1929-1930 przez Böhma, budującymi napięcie między zabudową miasta a nowoczesną, abstrakcyjną bryłą świątyni i związanych z nią budynków ${ }^{18}$. Herkommer tłumaczył stosowanie takich form w budowli kościelnej - zwłaszcza płaskich dachów - koniecznością „dotrzymywania kroku” przez budownictwo kultowe innym dziedzinom współczesnej architektury ${ }^{19}$.

Wnętrze kościoła św. Antoniego zaprojektowano nieco bardziej tradycyjnie niż jego zewnętrze i stanowi ono wariację na temat układu bazylikowego (il. 3-4). Jednak partie, które można by nazwać nawami bocznymi, nie są oddzielone od głównej podporami (ten typ wnętrza będę dalej nazywał za Christianem

Herkommer, Kirchliche Kunst..., s. 8.

Dominikus Böhm..., s. 131.

Ibidem, s. 13-15.

Manfred Speidel, Dominikus Böhm in Hindenburg 1928-1932 [w:] Dominikus Böhm..., s. $77-82$.

19 Herkommer, Kirchliche Kunst..., s. 9. 


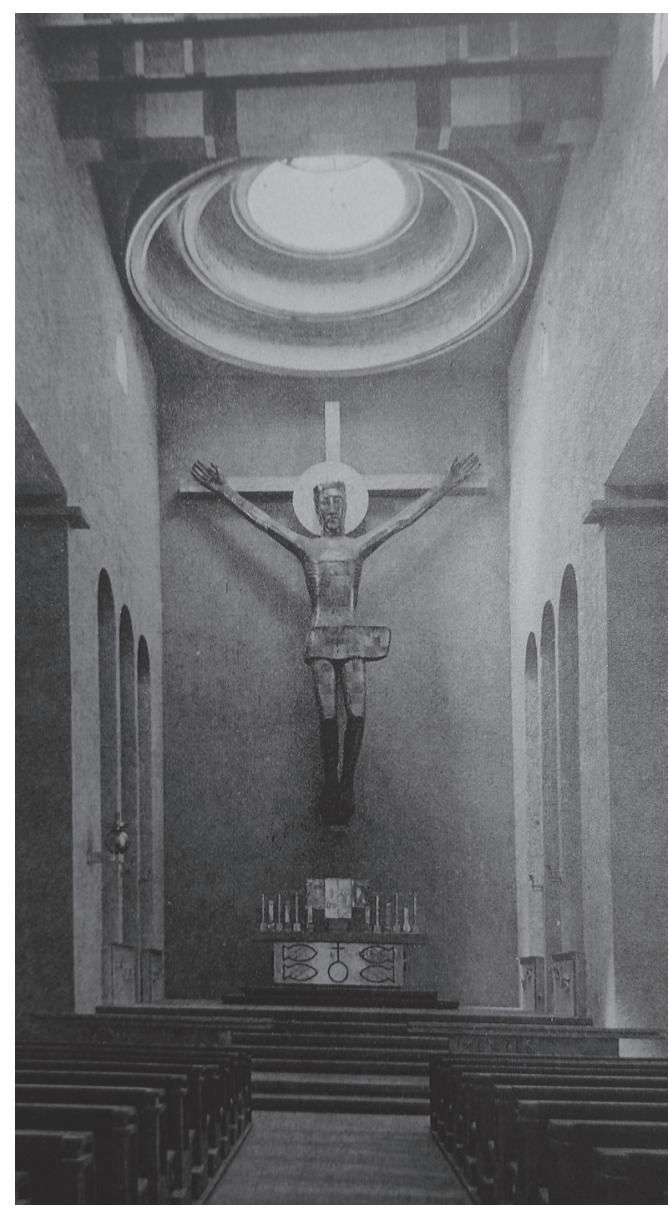

Il. 3. Hans Herkommer, kościół św. Antoniego w Pile, 1928-1930, wnętrze, widok w stronę prezbiterium, stan pierwotny, repr. za: Hans Herkommer, Kirchliche Kunst der Gegenwart, Stuttgart 1930
Welzbacherem bazyliką bezfilarową $\left.{ }^{20}\right)$. Tego rodzaju układ pojawia się niemal we wszystkich wspomnianych projektach kościołów Herkommera, w których przestrzeń została ukształtowana addycyjnie, w sposób przywodzący na myśl architekturę ottońską. Staranie opracowana kolorystyka wnętrza ścian pilskiej świątyni podkreślała podziały architektury: ściany naw bocznych utrzymane były w ciemnej szarości, natomiast ich stropy w bieli, zaś ściany głównej nawy oraz ściana tęczowa utrzymane były w jasnych, laserunkowych żółcieniach ${ }^{21}$. Na południowej ścianie bocznej korpusu nawowego (pozbawionej okien) mannheimski twórca Willy Oeser namalował stacje drogi krzyżowej, tworzące wyraźny akcent kolorystyczny we wnętrzu kościoła ${ }^{22}$. Podobną kompozycję kolorystyczną - kombinację ciemnych szarości i złamanych bieli - skontrastowaną z monumentalnym malowidłem ściennym zaplanował Herkommer w kościele św. Anny w St. Wendel, wybudowanym w tym samym czasie (1929-1930). Interesujący jest sposób ukształtowania stropu nawy głównej: podzielono go poprzecznie masywnymi, żelbetowymi belkami na pięć „przęsel” (którym odpowiada liczba okien północnej „nawy bocznej"), wpisując między nie po pięć mniejszych belek. Tło utrzymano przy tym w tonacji ciemnobrązowej, zaś belki pomalowano na biało; przecinały je malowane, sepiowe pasy, równoległe do osi kościoła, równoważące optycznie

20 Welzbacher, Kirchenbau und Moderne..., s. 37.

21 Wszystkie informacje na temat pierwotnej kolorystyki i wyposażenia zob. Jankiewicz, Kościół św. Antoniego..., s. 94-95, 109-119; cyt. za: Festschrift zur Einweihung der Antoniuskirche in Schneidemühl am 15. Juni 1930. Schneidemühl 1930; zob. też Heinrich M. Janssen, 50 Jahre St. Antoniusgemeinde Schneidemühl, Hildesheim 1980. Obecnie ściana ołtarzowa jest ciemnoczerwona, co zmienia charakter przestrzeni. O powojennych zmianach kolorystyki wnętrza kościoła zob. Jankiewicz, Kościół św. Antoniego... 2009, s. 95-97.

22 Ibidem, s. 100-102. 


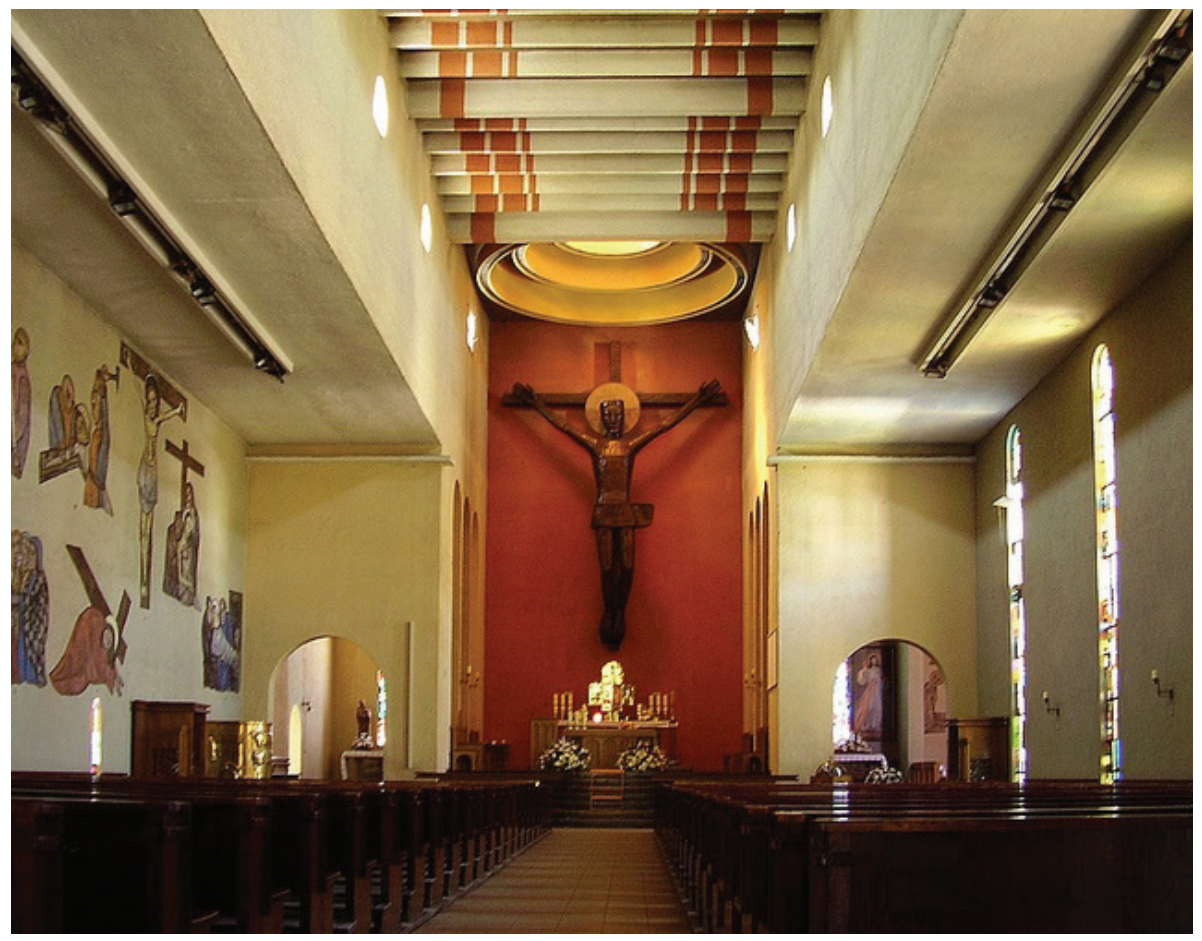

Dwa

kościoły...

Il. 4. Hans Herkommer, kościół św. Antoniego w Pile, 1928-1930, wnętrze, widok w stronę prezbiterium, stan obecny, repr. za: Tomasz Sachanowicz, Architektura w Szczecinie..., https:// www.blogger.com/profile/04175562884831164762

rytm belek ${ }^{23}$. Jednoprzęsłowe, prosto zamknięte prezbiterium flankowane jest kaplicami, otwartymi na tę część kościoła trójarkadowymi przeźroczami i połączonymi z nawą półkolistymi wejściami ${ }^{24}$. Nad prezbiterium Herkommer zaprojektował okrągłą latarnię z trójstopniowym tamburem o złoconych ścianach, nakrytą stożkowym, szklanym hełmem. Motyw ten pojawiał się sporadycznie już wcześniej, m.in. w kościele św. Henryka w Bambergu, wybudowanym przez Michaela Kurza w latach 1927-1929, gdzie zastosowano jednak bardziej tradycyjne formy, nawiązujące do architektury wczesnoromańskiej ${ }^{25}$. Herkommer operował natomiast abstrakcyjnymi formami, uzyskując znacznie bardziej ekspresyjny efekt. Dzięki wyzłoceniu ścian tamburu światło w prezbiterium

23 Jest to wyjątkowa kompozycja nie tylko na tle innych projektów Herkommera, lecz i całej architektury kultowej Niemiec tego czasu, zob. Anke Fissbare, Konstruktion und Raumform im Kirchenbau der Moderne: die Längsbinderkirchen von Hans Herkommer, „In situ” 2015, Bd. 7, H. 1, s. 117-124.

${ }^{24}$ W prawej kaplicy znajduje się wejście do kolejnej kaplicy, poświęconej św. Antoniemu Padewskiemu.

25 Ulrike Laible, Bauen für die Kirche. Der Architekt Michael Kurz (1876-1957), Berlin 2003, s. 54-57. 
Rafał nabiera ciepłej, alabastrowej barwy, oświetlając monumentalny drewniany Makała krucyfiks zawieszony na ścianie ołtarzowej (pierwotnie utrzymanej w tonacji fioletowo-czerwonej26). Ekspresyjna rzeźba Bertholda Müllera-Oerlinhausena, zamówiona specjalnie do kościoła w Pile ${ }^{27}$, stanowi dominantę wnętrza, będąc najważniejszym spośród nielicznych zaprojektowanych przez Herkommera elementów wyposażenia. Wiązało się to z powszechnie wyznawaną w środowisku architektów projektujących kościoły zasadą ograniczenia do minimum dekoracji i sprzętów liturgicznych, co miało służyć (podobnie jak redukcja architektury do podstawowych brył geometrycznych) powrotowi Kościoła katolickiego do pierwotnej prostoty, a w konsekwencji do stworzenia jasnego, zrozumiałego dla współczesnego człowieka przesłania. Uproszczona, skromnie dekorowana, a zarazem monumentalna i przemawiająca językiem nowoczesnych form architektura miała też wyrażać ideę kościoła jako wspólnoty wiernych (o czym Herkommer pisał w cytowanej tu już książce) ${ }^{28}$. Idea ta, jakkolwiek powszechna, była jednak różnie interpretowana. Christian Welzbacher przeciwstawia "niepatetyczną, racjonalną i w swojej prostocie niemal protestancką" architekturę budowli Herkommera kościołom Böhma, tworzącego wnętrza o mistycznym charakterze, służące przede wszystkim celebracji sacrum ${ }^{29}$. Z pewnością architektura sakralna katolików w międzywojennych Niemczech była mocno spolaryzowana i twórczość Böhma stanowiła jedno z jej ekstremów, trudno jednak postrzegać budowle Herkommera jako całkowite ich przeciwieństwo. To raczej projekty Schwarzta, jak słynny kościół Bożego Ciała w Akwizgranie (Fronleichnamkirche, 1929-1930) ${ }^{30}$, z ich całkowicie abstrakcyjnymi formami i skrajnym racjonalizmem, tworzą drugi biegun katolickiej architektury kultowej w międzywojennych Niemczech. Twórczość Herkommera lokuje się raczej między tymi ekstremami, co widać na przykładzie jego dwóch, bodaj najbardziej reprezentacyjnych budowli - kościołów we Frankfurcie i w Pile. W porównaniu $\mathrm{z}$ frankfurcką świątynią w kościele św. Antoniego Herkommer znacznie bardziej dystansuje się wobec tradycji, posługując się formami z repertuaru Neues Bauen, co jest - jego zdaniem - znakiem nie tylko nadążania przez Kościół katolicki za przemianami współczesnego świata, lecz także przewodzenia $\mathrm{im}^{31}$. We wnętrzu architekt starannie uwzględnił funkcje liturgiczne i symboliczne kościoła, jednak już sposób, w jaki zaprojektował

26 Obecnie efekt ten jest przytłumiony przez kolorystykę wnętrza.

27 Jankiewicz, Kościół śs. Antoniego..., s. 126-130.

28 Herkommer, Kirchliche Kunst..., s. 7.

29, „...] unpathetisch und sachlich, in ihrer Einfachheit fast protestantisch", zob. Welzbacher, Kirchenbau und Moderne..., s. 38.

30 Wolfgang Pehnt, St. Froleichnahm [w:] Wolfgang Pehnt, Hilde Strohl, Rudolf Schwarz, 1897-1961. Architekt einer anderen Moderne, Wien 1999, s. 70-77.

31 „Die katholische Kirche hat den Wert und die Notwendigkeit lebendiger Kunst, die aus dem Geist der Zeit geboren ist, von jeher erkannt und gefördert; sie anerkannte auch, dass jede Zeit die Berechtigung zu einem eigenen Ausdruck hat. So anerkannt und fördert sie auch heute wieder mit voller Absicht die Kunst unser Zeit", zob. Herkommer, Kirchliche Kunst..., s. 8. 
prezbiterium, z kopułą o złoconych tamburach i słupem światła opływającym ołtarz, bliższy jest „mistycznej” architekturze Böhma niż „protestanckiemu racjonalizmowi”.

Dlaczego jednak dzieło tak nowatorskie na tle oeuvre Herkommera zostało zrealizowane akurat w prowincjalnej Pile? Wpływ miała na to zapewne szczególna sytuacja prałatury, jednak istotne znaczenie miała przede wszystkim osoba bezpośredniego zleceniodawcy - prałata (od 1930 r. biskupa warmińskiego) Maksymiliana Kallera. Należał on do umiarkowanie reformatorskiego skrzydła Kościoła katolickiego, kładącego nacisk na sięganie po nowoczesne środki w pracy duszpasterskiej i wypracowanie nowej pozycji Kościoła w nowoczesnym społeczeństwie. W swojej wcześniejszej działalności na Rugii (1906-1917) i w Berlinie (1917-1926) Kaller dał się poznać jako energiczny organizator życia wspólnotowego i zwolennik włączania wiernych w działalność Kościoła. O ile przy tym przed pierwszą wojną światową był wierny historyzmowi, o tyle już podczas pobytu w Berlinie zaczął się skłaniać ku stosowaniu nowoczesnych form w architekturze i wyposażeniu kościołów ${ }^{32}$. Kościół św. Antoniego w Pile jest więc interesujący również jako świadectwo sięgania przez duchowieństwo katolickie po nowoczesne formy w celu dopasowania się do modernizującego się społeczeństwa i poszukiwania nowych formuł wizualizujących nowe koncepcje duszpasterstwa i nową wizję Kościoła - wiernego tradycji, ale sięgającego po nowe środki wyrazu. Architektura Herkommera, eksperymentatorska, spektakularnie nowoczesna, ale pozwalająca na pozostanie w kręgu liturgicznych przyzwyczajeń (zarówno hierarchii, jak i wiernych), mogła być postrzegana jako doskonale odpowiadająca tym potrzebom.

Drugi z wymienionych obiektów, ewangelicko-reformowany Kościół Krzyża (obecnie rzymskokatolicki kościół pw. Świętej Rodziny) w Szczecinie (il. 5-6), został zaprojektowany przez Adolfa Thesmachera - architekta, który w przeciwieństwie do Herkommera nigdy wcześniej nie miał do czynienia z budownictwem kultowym. Thesmacher (1880 Oldenburg - 1948 Brema) osiadł w Szczecinie w 1908 r. Budował wille (m.in. w obrębie powstającego od 1909 r. osiedla Ackermannshöhe ${ }^{33}$ ), a także domy wielorodzinne i budynki biurowe. Jego projekty niezwykle szybko wyewoluowały od neoromantycznych kompozycji w duchu Richarda Riemerschmieda w stronę zredukowanej, klasycyzującej

32 Wzniesione z jego inicjatywy na Rugii kościół św. Bonifacego w Bergen (August Kaufhold, 1911-1912) i kościół Marii Gwiazdy Morza w kurorcie Sellin (Heinrich Krings 1912) prezentują różne wersje neogotyku. Trzeba jednak pamiętać, że decyzje na temat form tych budowli były uzależnione od akceptacji kurii biskupiej. Dopiero po objęciu prałatury Kaller mógł sam podejmować takie decyzje. Na temat poglądów Kallera zob. Hans-Jürgen Karp, Rainer Bendel, Bischof Maximilian Kaller (1880-1947). Seelsorger in den Herausforderungen des 20. Jahrhunderts, Münster 2017, s. 42-66, 76-109, 117-131, 170-172.

33 Osiedle nie otrzymało po 1945 r. polskiej nazwy, zob. Rafał Makała, Między prowincja a metropolia. Architektura Szczecina w latach 1891-1918, Szczecin 2011, s. 322 n. 


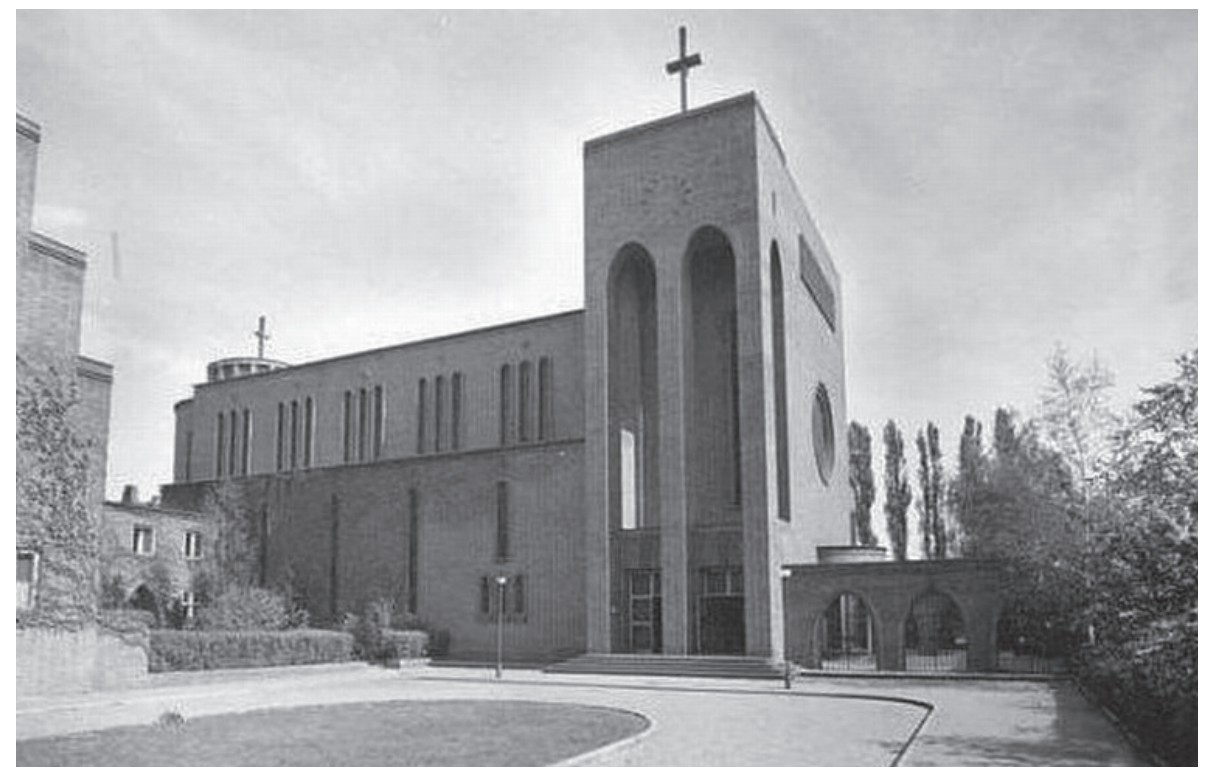

Il. 5. Adolf Thesmacher, dawny Kościół Krzyża (obecnie pw. Świętej Rodziny) w Szczecinie, 1929-1931, stan pierwotny, fot. ze zbiorów Muzeum Narodowego w Szczecinie

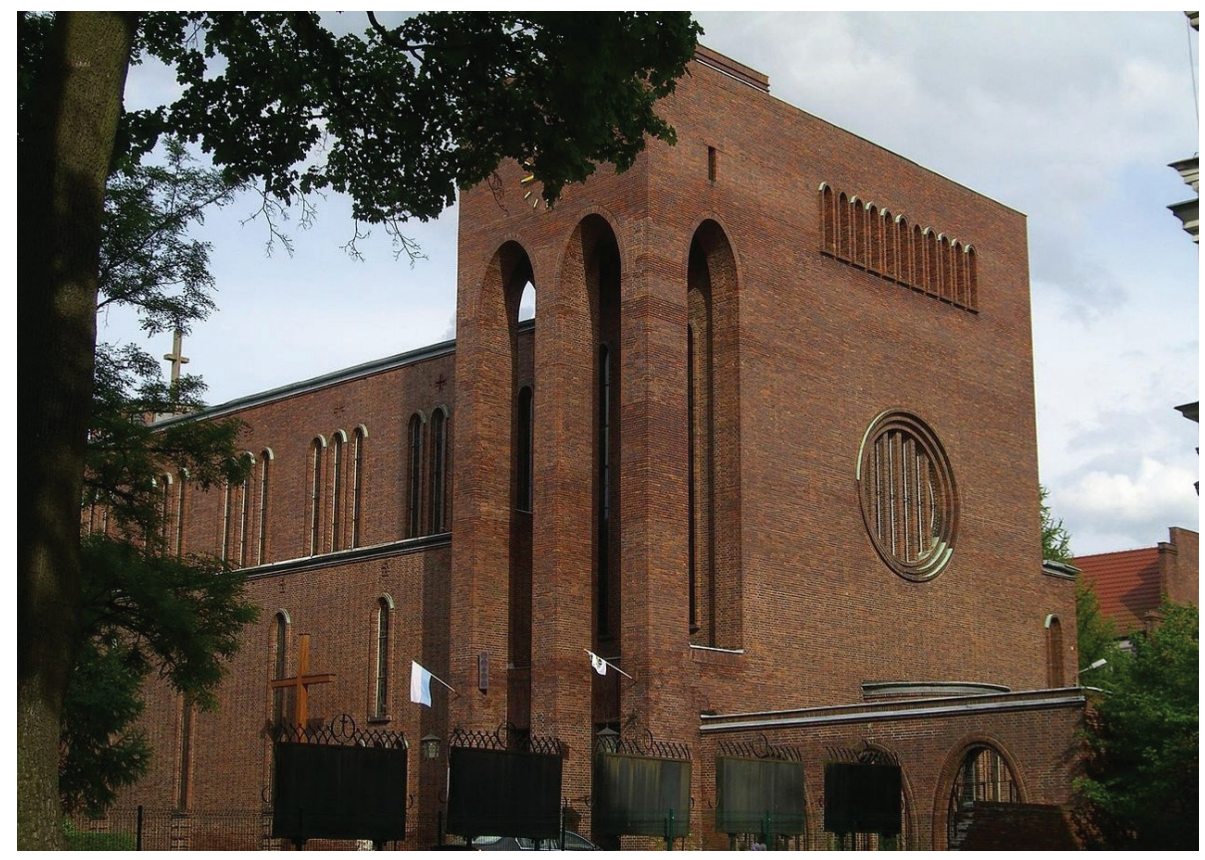

Il. 6. Adolf Thesmacher, dawny Kościół Krzyża (obecnie pw. Świętej Rodziny) w Szczecinie, 1929-1931, elewacja wieży, stan obecny, fot. Rafał Makała 
architektury przypominającej późne dzieła Petera Behrensa czy Albina Müllera ${ }^{34}$. Obecnie można tylko spekulować na temat powodów powierzenia Thesmacherowi zadania wybudowania kościoła - być może wpływ na to miały jego związki z elitą finansową Szczecina, dla której projektował domy i z którą miał do czynienia pracując m.in. dla koncernu papierniczego Feldmühle. Parafia, dla której wznoszono Kościół Krzyża, obejmowała bowiem teren dzielnicy Westend, na którym znajdowały się domy szczecińskiej i pomorskiej elity - Qustiorpów, Döringów czy Drewsów. Choć był to kolejny kościół parafialny wznoszony w szybko rozwijającym się mieście, oczekiwania wobec jego architektury były wyższe niż te, które stawiano obiektom wcześniej powstałym w robotniczym Ober-Bredow (obecnie Górne Drzetowo) czy urzędniczym Braunsfelde (obecnie część Pogodna ${ }^{35}$. Wybudowanie kościoła parafialnego dla Westendu planowano zresztą od końca XIX w., przeznaczając dlań reprezentacyjne miejsce na zamknięciu Kaiser-Wilhem-Strasse (obecnie Aleja Jana Pawła II), łączącej Stare Miasto z terenami parkowymi (parkiem Quistorpa) na północnym zachodzie Szczecina. Po zakończeniu pierwszej wojny światowej ulokowano jednak w tym miejscu siedzibę władz Prowincji Pomorskiej, wybudowaną w latach 1924-1927 przez Georga Steinmetza ${ }^{36}$. Kościół postanowiono wznieść przy Werderstrasse (obecnie ulica Królowej Korony Polskiej) - jednej z przecznic łączących główną arterię tej części miasta, Falkenwalderstrasse (obecnie Aleja Wojska Polskiego), z parkiem Quistorpa. Było to znacznie mniej prestiżowe miejsce, a przy tym działka, choć stosunkowo obszerna, przylegała do ulicy węższym bokiem, nie wpisując się w żadną oś widokową.

Thesmacher poradził sobie $\mathrm{z}$ tym problemem na dwa sposoby: po pierwsze, budowla została odsunięta w głąb działki, co pozwoliło na założenie niewielkiego dziedzińca przed fasadą kościoła; po drugie, architekt zaprojektował budowlę, wykorzystując położenie tak, by prezentowała się ona efektownie z różnych perspektyw między otaczającymi ją willami. Kościół wzniesiono równolegle do Werderstrasse, nadając dłuższej elewacji rolę fasady północno-zachodniej. W głębi działki wybudowano prostopadle do kościoła skrzydło mieszczące dalsze elementy zespołu domu parafialnego, m.in. salę parafialną, przedszkole i pomieszczenia dla konfirmantów. Od północnego wschodu plac przed kościołem zamknięto budynkiem plebanii, a z przeciwnej strony ceglanym murem, dzięki czemu już od skrzyżowania dawnych Werderstrasse i Falkenwalderstrasse kościół jawi się w monumentalizującej go perspektywie

34 Zob. Maciej Słomiński, Architekci wielkiego Szczecina, „Kronika Szczecina 2000” 2001, s. 69-71; Janusz Ławrynowicz, Adolf Thesmacher [w:] Encyklopedia Szczecina. Suplement 3, red. Tadeusz Białecki, Szczecin 2010, s. 111; Andrzej Androchowicz, Adolf Thesmacher, http:// encyklopedia.szczecin.pl/wiki/Adolf_Thesmacher [dostęp: 29.03.2020]; zob. też Makała, Między prowincja..., s. 322-323.

35 Ibidem, s. 72-73.

36 Bogdana Kozińska, Rozwój przestrzenny Szczecina od początku XIX w. do II wojny światowej, Szczecin 2002, s. 255. 
Rafat jako trójnawowa bazylika z wieżą tworzącą potężny „westwerk” ${ }^{37}$. Od strony Makała dziedzińca elewację wieży stanowi kolosalny trójarkadowy portyk z łukami parabolicznymi, uderzająco podobny do tego, który Herkommer zaprojektował w Pile zaledwie rok wcześniej.

W przeciwieństwie do kościoła św. Antoniego elewacje szczecińskiej budowli w całości pokryto ciemnoczerwonym klinkierem, z którego wykonano też wszystkie dekoracje. Posłużenie się ceglanym materiałem było w Szczecinie oczywistym odwołaniem zarówno do tradycji lokalnej, pomorskiej, jak i szerszej, północnoniemieckiej, tyleż odkrywanej, co kreowanej w drugiej połowie XIX i w początkach XX w. ${ }^{38}$ Wielki masyw wieżowy mógł się też kojarzyć z jednym z najbardziej znanych ówcześnie zabytków średniowiecznych - kolegiatą (obecnie konkatedrą) Mariacką w Kołobrzegu, do której - jako przykładu „westwerku” - nawiązywał w swoich projektach m.in. Böhm ${ }^{39}$. Zaprojektowany przez Thesmachera „masyw zachodni” widoczny jest również od strony dawnej Falkenwalderstrasse, między willami (il. 6). Dopiero z tej perspektywy fasada wieży prezentuje się w całej okazałości, z portykiem i ogromnym oculusem, co z pewnością było zamysłem architekta, Falkenwalderstrasse była bowiem ulicą, przy której mieszkało wiele rodzin należących do elity Szczecina i Pomorza. To właśnie z tej perspektywy Kościół Krzyża miał być oglądany po raz pierwszy.

Między „westwerkiem” a murem ograniczającym dziedziniec od zachodu Thesmacher zaprojektował niewielki podwórzec, nawiązujący do perystylu wczesnochrześcijańskich bazylik. Między wieżą a murem granicznym założono niewielki dziedziniec, od strony placu - z trzema arkadami o parabolicznych łukach. Istotnym elementem tej przestrzeni jest elewacja wieży z obszerną absydą stanowiącą dominantę całej kompozycji, w zasadzie niewidocznej od strony fasady. Tak ukształtowany „perystyl” nie miał żadnych funkcji liturgicznych, był natomiast ważnym elementem budowli ze względów estetycznych, a przede wszystkim symbolicznych - poprzez nawiązanie do tradycji wczesnochrześcijańskiej, która stanowiła jeden z najważniejszych punktów odniesienia ruchu reformy Kościoła ewangelickiego w międzywojennych Niemczech ${ }^{40}$.

Thesmacher zaprojektował bryłę Kościoła Krzyża - podobnie jak Herkommer kościoła św. Antoniego - addycyjnie zestawiając kubiczne, jasno wykreślone elementy kompozycji. Obie budowle upodabnia także odwołanie do schematu bazyliki z potężnym „masywem zachodnim”. Ani jedno, ani drugie nie stanowiło, rzecz jasna, cechy charakterystycznej architektury Herkommera, podobnie jak

37 Wieża w rzeczywistości zwrócona jest na południowy zachód, jednakże termin ten oddaje intencje autora. W ten sam sposób określa ten element Stefańska, Architektura kompromisu..., s. $451-452$.

38 Zob. Rafał Makała, Nawiązania do tradycji nowożytnej w ceglanej architekturze wczesnomodernistycznej pólnocnych Niemiec, „Porta Aurea” 2018, t. 17, s. $94-111$ (tamże literatura przedmiotu).

39 Dominikus Böhm..., s. 49.

40 Herkommer, Kirchliche Kunst..., s. 7. 
wąskie, wydłużone okna, był nią natomiast kolosalny portyk z boku masywnej wieży. Pojawia się on po raz pierwszy właśnie w kościele św. Antoniego, a powtórzony zostaje przez Thesmachera. Ze względu na czasową i przede wszystkim geograficzną bliskość obu realizacji nie sposób nie widzieć w budowli Herkommera bezpośredniej inspiracji dla Kościoła Krzyża, zwłaszcza w kontekście zastosowania przez Thesmachera ceglanego tworzywa. O ile bowiem elewacje kościoła św. Antoniego mają naśladować „białą architekturę” modernizmu, o tyle klinkierowe ściany Kościoła Krzyża odwołują się do tradycji północnoniemieckiej (w rozumieniu powszechnym w międzywojennych Niemczech, z uwzględnieniem Niderlandów i Inflant ${ }^{41}$ ). Elewacje szczecińskiej budowli nie są też pozbawione dekoracji w takim stopniu jak w Pile, jednak Thesmacher operuje wyłącznie abstrakcyjnymi formami - i to bardzo oszczędnie. Dekoracje przy tym nie z kształtek, lecz z cegieł wysuniętych nieco przed lico muru, co nadaje im bardzo sumaryczny charakter. Posłużenie się ceglanym tworzywem w kompozycji elewacji lokuje szczeciński Kościół Krzyża w stosunkowo licznej grupie budowli kultowych - protestanckich i katolickich - należących do nurtu tzw. ceglanego modernizmu. Po takie rozwiązania sięgał oczywiście Böhm ${ }^{42}$, ale też mniej znani twórcy, jak Albert Boßlet czy Jan Huber Pinand ${ }^{43}$. Zastosowana przez Thesmachera formuła jest też bliska architekturze ceglanego modernizmu Hamburga, Bremy czy Szlezwiku-Holsztyna (przede wszystkim dziełom Fritza Schumachera i Fritza Högera), duńskiemu ekspresjonizmowi Pedera i Kaare Klintó $w^{44}$, a nawet architekturze szkoły amsterdamskiej (na to ostatnie podobieństwo wskazała Alina Stefańska ${ }^{45}$ ). Jednak w tym kontekście dzieło Thesmachera wyróżnia się sposobem komponowania bryły i powściągliwością, a także abstrakcyjnymi formami dekoracji, co daje efekt być może nie mniej ekspresyjny niż w pracach wspomnianych architektów, z pewnością jednak osiągnięty innymi środkami. Najbliższą w tym względzie dziełu Thesmachera realizację stanowi wybudowany przez Josefa Bachema i Heinricha Horvatina katolicki kościół św. Marcina w Kaulsdorfie (1929-1930, obecnie dzielnica Berlina). Jest to jednak dzieło powstałe równocześnie $\mathrm{z}$ budowlą

${ }_{41}$ Zob. Rafał Makała, Neorenesans pótnocny jako niemiecki styl narodowy na przełomie XIX i XX w. [w:] Recepcja renesansu w XIX i XX w. Materiały Sesji Stowarzyszenia Historyków Sztuki, Łódź, listopad 2002, red. Małgorzata Wróblewska-Markiewicz, Łódź 2003, s. 307-314.

${ }_{42}$ M.in. we wspomnianym już kościele Chrystusa Króla w Bischofsheim (choć tu nawiązania do gotyku są znacznie bardziej dosłowne) czy w jego najbardziej znanym dziele - kościele św. Józefa w Zabrzu (wybudowanym w latach 1930-1931, a więc późniejszym niż Kościół Krzyża).

43 Clemens Jöckle, Albert Boßlet (1880-1957). Ein Kirchenbaumeister zwischen Historismus und Moderne, „Jahrbuch des Vereins für Christliche Kunst in München” 1993, Bd. 19, s. 542-617; Karl Busch, Pinand, Jan Hubert [w:] Allgemeines Lexikon der Bildenden Künstler von der Antike bis zur Gegenwart. Begründet von Ulrich Thieme und Felix Becker, Bd. 27, Piermaria-Ramsdell, Hg. Hans Vollmer, Leipzig 1933, s. 50-51.

${ }_{44}$ Jens Rieser, Die Katholische Pfarrkirche St. Martin in Kaulsdorf und der Kruzifixus von Hans Perathoner [w:] Anja Franziska Denker, Lothar Hermann, Die Denkmale in Berlin. Bezirk Marzahn-Hellersdorf, Berlin 2002, s. 130-137.

45 Stefańska, Architektura kompromisu..., s. 455-456, 459. 


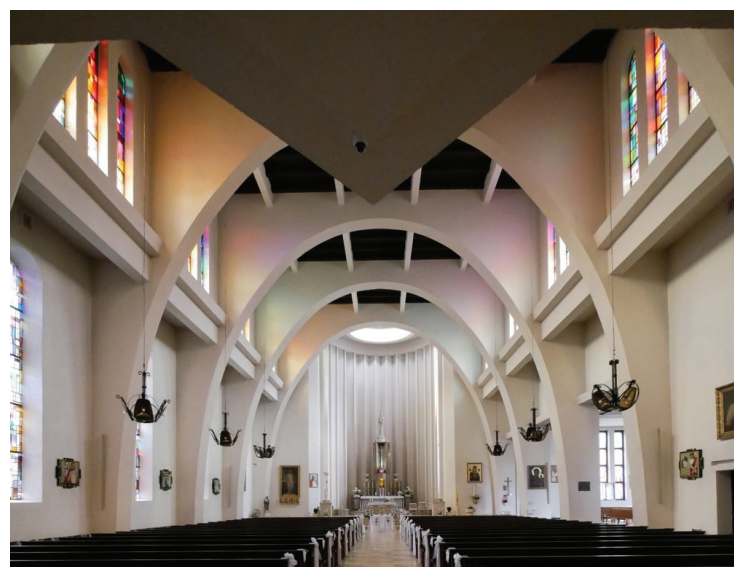

Il. 7. Adolf Thesmacher, dawny Kościół Krzyża (obecnie pw. Świętej Rodziny) w Szczecinie, 1929-1931, wnętrze, stan obecny, fot. Eckart Wittmann

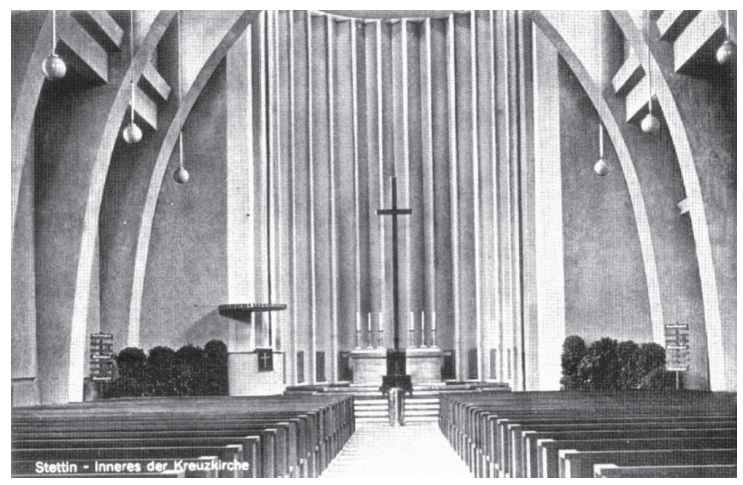

Il. 8. Adolf Thesmacher, dawny Kościół Krzyża (obecnie pw. Świętej Rodziny) w Szczecinie, 1929-1931, wnętrze, stan pierwotny, repr. za: Tomasz Sachanowicz, Architektura w Szczecinie..., https://www.blogger.com/ profile/04175562884831164762

Thesmachera, może być zatem rozważane jako inny przykład recepcji „białej architektury” modernizmu w ceglanym budownictwie kultowym, a nie jako inspiracja.

Wnętrze Kościoła Krzyża zaskakuje (nie tylko w zestawieniu z formami użytymi na zewnątrz) - przede wszystkim frapującym rozwiązaniem przestrzeni (il. 7-8). Świątynia, prezentująca się od zewnątrz jako bazylika, jest w istocie obszerną halą z belkowanym stropem, wspieranym przez sześć monumentalnych łuków parabolicznych, które dzielą przestrzeń na wyraźnie zaznaczone przęsła. To, co z zewnątrz wydaje się boczną nawą, jest tylko uskokiem bocznych ścian, poprzecinanym łukami. Widz ma zatem przed sobą dwie nakładające się na siebie struktury: jedną tworzy wyznaczany płaszczyznami ścian, wyraźnie zaznaczony schemat „bazyliki bezfilarowej”, drugą zaś rytm potężnych łuków, stanowiący kulisową strukturę niczym dekoracja teatralna czy nowożytne studium perspektywy. Tak ukształtowane wnętrze przypomina m.in. hangar dla sterowców, uznawany ówcześnie za przykład najbardziej progresywnego typu architektury ${ }^{46}$. Elementem łączącym dwa modele wnętrza kościelnego jest strop z czterema wąskimi wzdłużnymi belkami, na których wspierają się mniejsze belki poprzeczne. Oczywiście pomysł stworzenia wnętrza kościoła w oparciu o szereg parabolicznych łuków pojawił się w Niemczech znacznie wcześniej i był realizowany wielokrotnie, m.in. we wspomnianym już kościele Böhma w Bischofsheim (1924-1925), jednak zwykle w opozycji do „pudełkowego” typu addycyjnego wnętrza, znacznie częściej w kościołach katolickich niż protestanckich. Thesmacher nie poprzestał jednak na zastosowaniu

46 Na temat hangarów dla sterowców w Niemczech zob. John Provan, Die Deutsche Luftschiffhalle, Kelkheim 2001. 
tego rozwiązania, ale połączył je z addycyjnym, „pudełkowym” typem przestrzeni, budując w ten sposób napięcie nadające wnętrzu ekspresyjny charakter. Tego rodzaju rozwiązania były w tym czasie dość rzadkie. W budownictwie katolickim zastosował je m.in. Herkommer - w kościele bł. Henryka Suzona (niem. Suso-Gedächtniskirche) w Ulm, powstałym w latach 1927-1928 (zniszczonym w czasie drugiej wojny światowej) ${ }^{47}$, czy Otto Linder - w kościele Wniebowzięcia Matki Boskiej w Süßen w dzisiejszej Badenii-Wirtembergii, wzniesionym w latach 1929-1930. Natomiast jednym z najbardziej spektakularnych przykładów protestanckich jest kościół przy Hohenzollernplatz w Berlinie-Wilmersdorfie, wybudowany w latach 1930-1934 przez Ossipa Klarweina (pracującego w biurze Fritza Högera $)^{48}$. O ile kościoły Lindnera i Klarweina powstały równocześnie lub nawet później niż szczecińska budowla, o tyle powstanie świątyni w Ulm bezpośrednio poprzedza wybudowanie Kościoła Krzyża. Nie sposób jednak rozstrzygnąć, czy Thesmacher mógł znać ten obiekt - publikacje na temat kościoła w Ulm pojawiły się w 1929 r., gdy trwały już prace przy budowie szczecińskiego kościoła.

Zamykające perspektywę prezbiterium ma kształt rotundy otwartej w stronę nawy, o ścianach dekorowanych pionowymi listwami o trójkątnym przekroju, oświetlonej latarnią oraz - niewidocznymi z nawy - oknami wpisanymi między listwy przy łuku tęczowym. Związek tego rozwiązania z dziełem Herkommera jest mniej wyraźny niż w przypadku portyku wieży, ale nadal niewątpliwy. Thesmacher poszedł jednak dalej w teatralizacji kompozycji, wprowadzając ukryte okna. Zaplanowanie prezbiterium jako rotundy dynamizuje kompozycję, zaś wprowadzenie dekoracji listwowej służy jej wertykalizacji i monumentalizacji (nota bene prezbiterium kościoła wygląda w ten sposób jak negatyw trzonu kolumny). W efekcie kompozycja prezbiterium jest tu znacznie bardziej ekspresyjna niż w kościele św. Antoniego. Wnętrze protestanckiej budowli kultowej ma zatem - paradoksalnie - bardziej mistyczny charakter niż wnętrze świątyni katolickiej.

Protestancki charakter kościoła ujawnia się w sposobie powiązania go z salą parafialną, przylegającą prostopadle do korpusu nawowego od południowego wschodu. Ściana boczna trzech przęseł od strony łuku tęczowego została zastąpiona harmonijkowymi drzwiami; po ich otwarciu sala stawała się drugą nawą kościoła - niższą i skromniejszą, ale pozwalającą widzieć kaznodzieję na ambonie. Dzięki połączeniu jej z nawą tworzyła się przestrzeń w kształcie litery „L" - schemat znany w protestanckim budownictwie kultowym od XVI w., często przywoływany w okresie międzywojennym w rozważaniach teoretyczno-estetycznych i dotyczących liturgii ${ }^{49}$. Możliwość szybkiego przekształcenia wnętrza kościoła była też próbą zastosowania nowatorskiego, funkcjonalnego

47 Zob. „Wasmuths Monatshefte für Baukunst und Städtebau” 1929, Bd. 13, s. 178-182. Dziękuję Prof. Tomaszowi Torbusowi za znalezienie tego artykułu.

48 Sibylle Badstübner-Gröger, Michael Bollé, Ralph Paschke, Berlin, Berlin-München $2000^{2}$ (Handbuch der Deutschen Kunstdenkmäler Georg Dehio, 8), s. 496.

49 Welzbacher, Kirchenbau und Moderne..., s. 39. 
Rafat rozwiązania przestrzennego w oparciu o nowoczesne technologie. Już przed Makała pierwszą wojną światową pojawiały się w środowisku ewangelików niemieckich głosy postulujące powrót do źródeł reformacji i projektowania kościoła przede wszystkim jako neutralnej przestrzeni Predigtkirche. W latach dwudziestych kładziono też nacisk na techniczne i strukturalne innowacje jako punkt wyjścia do tworzenia nowych typów wnętrz, bardziej adekwatnych (niż tradycyjne) do wypełniania zadań, jakie stały przed Kościołem w nowoczesnym społeczeństwie. Od połowy lat dwudziestych najbardziej wyrazisty nurt protestanckiego budownictwa kultowego wyznaczały teoretyczne rozważania i dzieła Otto Bartninga, postulującego konsekwentne odrzucenie wszelkich historycznych wzorów (w tym również odwoływania się do lokalnej tradycji) oraz elementów symbolicznych czy narracyjnych ${ }^{50}$. Jednak Thesmacher projektując Kościół Krzyża, postąpił wbrew tym zasadom i stworzył budowlę w czytelny sposób odwołującą się do tradycji, a ponadto zbudował we wnętrzu ekspresyjną, niemal mistyczną atmosferę, upodabniającą kościół do świątyń katolickich. Punktem wyjścia była dla niego jednak nie historyczna architektura kultowa, lecz budowane ówcześnie kościoły, posługujące się językiem międzynarodowej awangardy. Zważywszy na cytaty z dzieła Herkommera, można uznać kościół św. Antoniego za inspirację dzieła Thesmachera i punkt wyjścia jego projektu. Abstrakcyjną koncepcję bryły kościoła Thesmacher przekształcił w duchu ceglanej architektury ekspresjonizmu, nie tracąc przy tym zasadniczych cech pierwowzoru: kubiczności i addycyjnej kompozycji bryły.

Budownictwo ceglanego gotyku było przedmiotem fascynacji architektów modernizmu właśnie jako styl architektury dawnej, umożliwiający niemal nieograniczoną ekspresję $e^{51}$, jednak dosłowność odwołań do późnego historyzmu zastąpiono metaforycznością, a cytaty z historycznej architektury - abstrakcyjnymi formami pełniącymi rolę znaków. Z takich właśnie znaków, w swej podstawowej formie abstrakcyjnych, ale w kontekście zyskujących wyraźne znaczenie, Thesmacher skomponował Kościół Krzyża, czyniąc nowoczesność swego rodzaju „figurą retoryczną”, używaną w podobny sposób jak symbole przeszłości. W tym ujęciu dzieło Themachera można scharakteryzować słowami, którymi Christian Welzbacher opisał architekturę Böhma: „Aspekty tradycji i postępu istnieją w jego dziele nie obok siebie, lecz splecione w jedną, artystyczną całość" 52 .

Omówione powyżej kościoły prezentują wszystkie najważniejsze tendencje widoczne w architekturze kultowej międzywojennych Niemiec - od nurtu posługującego się językiem formalnym międzynarodowej awangardy po ceglany ekspresjonizm. Budowle te lokują się na przeciwstawnych pozycjach, mają jednak

Otto Bartning, Vom neuen Kirchenbau, Berlin 1919, s. 55.

Pehnt, Deutsche Architektur..., s. 105-106.

52 „Aspekte von Tradition und Fortschritt stehen in seinem [Böhm] Werk nicht nebeneinander, sondern sind zu einem künstlerischen Geflecht verwoben”, zob. Welzbacher, Kirchenbau und Moderne..., s. 40. 
wyraźnie cechy wspólne. Oczywiście Thesmacher zaczerpnął kilka rozwiązań z projektu Herkommera, ale tym, co istotnie łączy oba dzieła, jest śmiałe dążenie do eksperymentowania. Kościół św. Antoniego jest świadectwem poszukiwania form wyrażających racjonalistyczne dążenia do odnowy Kościoła katolickiego, jednak bez rezygnowania z zasad liturgii czy podważania magisterium. Herkommer sięga w tym celu po ,industrialne” formy, tworząc obiekt wyraźnie awangardowy nie tylko w kontekście małego, granicznego miasta wschodnich Niemiec, lecz także katolickiej tradycji architektury sakralnej. Thesmacher natomiast, budując kościół dla elity wielkiego protestanckiego miasta północnych Niemiec, sięga po formy stosowane przede wszystkim w świątyniach katolickich. Dzięki temu udaje mu się stworzyć obiekt wyrażający przywiązanie do lokalnej tradycji i jednocześnie manifestujący nowoczesność Kościoła ewangelickiego. W efekcie oba kościoły są świadectwem dążeń funkcjonalistycznych - choć oczywiście funkcji innych niż te, na których skupiali się np. twórcy Bauhausu.

\section{Bibliografia}

Androchowicz Andrzej, Adolf Thesmacher [w:] Encyklopedia Pomorza Zachodniego-pomeranica, pl, http://encyklopedia.szczecin.pl/wiki/Adolf_Thesmacher [dostęp: 29.03.2020].

Badstübner-Gröger Sibylle, Bollé Michael, Paschke Ralph, Berlin, Berlin-München ${ }^{2} 2000$ (Handbuch der Deutschen Kunstdenkmäler Georg Dehio, 8).

Brennecke Hans Christoph, Protestantischer Kirchenbau an der Wende zum 20. Jahrhundert [w:] Geschichte des protestantischen Kirchenbaues. Festschrift für Peter Poscharsky zum 60. Geburtstag, Hg. Klaus Raschzok, Reiner Sörries, Erlangen 1994.

Busch Karl, Pinand, Jan Hubert [w:] Allgemeines Lexikon der Bildenden Künstler von der Antike bis zur Gegenwart. Begründet von Ulrich Thieme und Felix Becker, Bd. 27, Piermaria-Ramsdell, Hg. Hans Vollmer, Leipzig 1933, s. 50-51.

Dominikus Böhm (1880-1955), Raum ist Sehnsucht. Der Kirchenbaumeister Dominikus Böhm 1888-1955 [katalog wystawy], Hg. Wolfgang Voigt, Ingeborg Flagge, Deutsches Architekturmuseum, Frankfurt am Main, Tübingen-Berlin 2005

Chojecka Ewa, Kościót św. Józefa w Zabrzu na tle krajobrazu artystycznego Górnego Ślaska, Katowice 1999.

Durth Werner, Pehnt Wolfgang, Wagner-Conzelmann Sandra, Otto Barning, Architekt einer sozialen Moderne, Darmstadt 2017.

Dawidowski Robert, Długopolski Ryszard, Szymski Adam M., Architektura modernistyczna lat 1928-1940 na obszarze Pomorza Zachodniego, Szczecin 2001.

Dittmann Marlen, Die Baukultur im Saarland 1904-1945, „Saarland Hefte” 2004, Bd. 3, s. $45-47$.

Festschrift zur Einweihung der Antoniuskirche in Schneidemühl am 15. Juni 1930. Schneidemühl 1930.

Fissbare Anke, Konstruktion und Raumform im Kirchenbau der Moderne: die Längsbinderkirchen von Hans Herkommer, „In situ." 2015, Bd. 7, H. 1, s. 117-124. 
Rafat Geschichte der Kirchen in Sankt Marien, Hg. Kirchengemeinde Sankt Marien Frankfurt Makała am Main, Frankfurt am Main 2017.

Glińska Maria, Niderlandyzm w sztuce Pomorza Zachodniego w czasach nowożytnych [w:] Niderlandyzm w sztuce polskiej. Materiały Sesji Stowarzyszenia Historyków Sztuki, Toruń, grudzień 1992, red. Tadeusz Chrzanowski, Warszawa 1995, s. 186-188.

Gorzelik Jerzy, Kościót św. Józefa w Zabrzu - arcydzieło architektury sakralnej, „Zeszyty Edukacji Kulturalnej" 2005, t. 48, s. 154-163.

W.H. [Hegemann, Werner], Die Frauenfriedenskirche in Frankfurt am Main. Architekt: Hans Herkommer, „Wasmuths Monatshefte für Baukunst und Städtebau” 1930, Bd. 14, s. 406-410.

Heyen Helmut, Dieyty Kirchen Stettins und ihre Geschichte, Stettin 1936.

Jankiewicz Patryk, Kościót św. Antoniego w Pile. Przewodnik. Piła 2009.

Janssen Heinrich M., 50 Jahre St. Antoniusgemeinde Schneidemühl, Hildesheim 1980.

Jöckle Clemens, Albert Boßlet (1880-1957). Ein Kirchenbaumeister zwischen Historismus und Moderne, „Jahrbuch des Vereins für Christliche Kunst in München” 1993, Bd. 19, s. 542-617.

Karp Hans-Jürgen, Bendel Rainer, Bischof Maximilian Kaller (1880-1947). Seelsorger in den Herausforderungen des 20. Jahrhunderts, Münster 2017.

Klauser Manuela, Ikonische Kirchen. Pfarrkirchenbau an Rhein und Ruhr zwischen Historismus und Moderne, Regensburg 2019.

Kozińska Bogdana, Rozwój przestrzenny Szczecina od poczatku XIX w. do II wojny światowej, Szczecin 2002.

Laible Ulrike, Bauen für die Kirche. Der Architekt Michael Kurz (1876-1957), Berlin 2003.

Gerhard Langmaack, Evangelischer Kirchenbau im 19. Und 20. Jahrhundert. Geschichte - Dokumentation - Synopse, Kassel 1971.

Ławrynowicz Janusz, Adolf Thesmacher [w:] Encyklopedia Szczecina. Suplement 3, red. Tadeusz Białecki, Szczecin 2010, s. 111.

Makała Rafał, Między prowincją a metropolią. Architektura Szczecina w latach 1891-1918, Szczecin 2011.

Makała Rafał, Nawiazania do tradycji nowożytnej w ceglanej architekturze wczesnomodernistycznej pótnocnych Niemiec, „Porta Aurea” 2018, t. 17, s. 94-111.

Makała Rafał, Neorenesans pótnocny jako niemiecki styl narodowy na przełomie XIX i XX w. [w:] Recepcja renesansu w XIX i XX w. Materiaty Sesji Stowarzyszenia Historyków Sztuki, Łódź, listopad 2002, red. Małgorzata Wróblewska-Markiewicz, Łódź 2003, s. 307-314.

Moderne Architektur exemplarisch. Hans Herkommer (1887-1956), Hg. Mathias Schirren, Kaiserslautern 2010.

Pehnt, Wolfgang, St. Froleichnahm [w:] Wolfgang Pehnt, Hilde Strohl, Rudolf Schwarz, 1897-1961. Architekt einer anderen Moderne, Wien 1999, s. 70-77.

Pehnt Wolfgang, Deutsche Architektur seit 1900, Ludwigsburg-München 2006.

Pehnt Wolfgang, Die Plangestalt des Ganzen. Der Architekt und Stadtplaner Rudolf Schwarz (1897-1961) und seine Zeitgenossen, Köln 2011.

Provan John, Die Deutsche Luftschiffhalle, Kelkheim 2001.

Rieser Jens, Die Katholische Pfarrkirche St. Martin in Kaulsdorf und der Kruzifixus von Hans Perathoner [w:] Anja Franziska Denker, Lothar Hermann, Die Denkmale in Berlin, Bezirk Marzahn-Hellersdorf, Berlin 2002, s. 130-137. 
Risse Heike, Frühe Moderne in Frankfurt am Main. 1920-1933, Frankfurt am Main 1984. Słomiński Maciej, Architekci wielkiego Szczecina, „Kronika Szczecina 2000”, Szczecin 2001.

Spaemann Heinrich, Acken, Johannes van [w: Lexikon für Theologie und Kirche, Hg. Josef Höfer, Karl Rahner, t. 1, Freiburg im Breisgau 1957.

Stefańska Alina, Architektura kompromisu. Europejskie źródła i szczecińskie realizacje. Analiza języka formalnego Adolfa Thesmachera na przykładzie kościołów pw. Królowej Korony Polskiej iśw. Andrzeja Boboli (Kreuzes- i Nicolaikirche) w Szczecinie, „Materiały Zachodniopomorskie” 1996, t. 42, s. 449-452, 454-460.

Wąs Cezary, Antynomie współczesnej architektury sakralnej, Wrocław 2008.

Welzbacher Christian, Kirchenbau und Moderne (1920-1940). Anmerkungen zu einer traditionsgebundenen Baugattung, „Kritische Berichte” 2007, Bd. 35, H. 1, s, 33-46.

Zabłocka-Kos Agnieszka, Sztuka. wiara. uczucie. Alexis Langer - śląski architekt neogotyku, Wrocław 1996.

Żurawska Ewa M., Twórczość Dominikusa Böhma na Śląsku, „Przestrzeń i Forma” 2012, nr 16, s. 623-654; nr 17, s. 517-530; nr 18, s. 291-304.

\section{Two Churches. Church Architecture in Interwar Germany as an Area for Modern Experiments}

The time between WW I and II was a period of intensive development of church architecture in Germany. In the new situation after the defeat in WW I on the wave of Christian renewal movements, the concept of the church as a building corresponding to its functions, as an object expressing the character of religion and the vision of a congregation as a community in modern society was re-formulated. The dynamically developing church architecture was an area of intense experiments (especially in the 1920s.), creating new forms, as well as devising new iconography by Rudolf Schwartz, Otto Bartning, or Dominikus Böhm. The paper draws attention to a certain community of the main antagonized Christian and Protestant denominations on the example of two buildings erected on the eastern periphery of the then Germany (from 1945 constituting the western part of Poland): the Catholic Church of St Anthony in Schneidemühl (now: Piła, Hans Herkommer, 1928-1930) and the Protestant Cross-Church in Stettin (now: Szczecin, Adolf Thesmacher, 1929-1931). The first was built in a small town as a representative seat of the Prelature, a branch of the Catholic Church in the Protestant region, near the then border with (revived again) Poland. The building is a continuation of an innovative and conservative concept realized by Herkommer at the Frauenfriedenskirche in Frankfurt am Main (1927-1929), and is a testimony to the search for forms expressing the rationalist aspirations for the renewal of the Catholic Church, however without abandoning the main principles of the Tradition. For this purpose, Herkommer applies 'industrial' forms used in the Bauhaus circle, creating a clearly avant-garde building: not only in the local context of a small border town of eastern Germany, but also in the Catholic tradition of sacred architecture. Hiring an avant-garde architect and using modernist forms was the decision of one man: Monsignor Maximilian Kaller, the leader of the Prelature. The Church of the Cross in Szczecin was raised in a luxurious district of a great Protestant city, so it was the parish church of the Protestant elite. Although built 
Rafat of brick and clearly referring to the tradition of the Gothic architecture of this region, Makała the Church of the Cross also reveals its striving for the maximum reduction of forms and the use of the language of abstraction. When building a Protestant church, Thesmacher resorted to forms applied primarily in Catholic architecture, especially to the forms used by Herkommer. Thesmacher created a facility expressing attachment to the local tradition and manifesting the modernity of the Evangelical church in Pomerania. As a result, both churches are a testimony to functionalist aspirations, although, of course, the functions differed from those on which, for example, the founders of the Bauhaus were focused. 